Website: http://journal.hibiscuspublisher.com/index.php/AJPB/index
BUBLISHER

\title{
Study of Ethnoveterinary Medicinal Plants Used by Pastoralists in Northern Gombe State, Nigeria
}

\author{
Mustapha Hassan ${ }^{1}$ and Usman Abubakar Yuguda ${ }^{1 *}$ \\ ${ }^{1}$ Department of Botany, Faculty of Science, Gombe State University P.M.B 127, \\ Tudun Wada, Gombe, Gombe State, Nigeria. \\ *Corresponding author: \\ Dr. Usman Abubakar Yuguda, \\ Department of Botany, \\ Faculty of Science, \\ Gombe State University \\ P.M.B 127, \\ Tudun Wada, \\ Gombe, \\ Gombe State, \\ Nigeria. \\ Email: uayuguda@gsu.edu.ng
}

\section{HISTORY \\ Received: $24^{\text {th }}$ Aug 2021 \\ Received in revised form: $15^{\text {th }}$ Nov 2021 Accepted: $3^{\text {rd }}$ Dec 2021}

\section{KEYWORDS \\ Ethnoveterinary \\ Pastoralists
Gombe-Abba \\ Gombe-Abba \\ Deforestation
Diversity}

\begin{abstract}
Ethnoveterinary is the total of all practices that enable man to prevent his livestock from diseases, alleviate and relieve suffering to bring about healing, and increase the production and productivity of livestock within a minimum cost. Overutilization, overexploitation, deforestation for fuelwood, and farmland expansion expose some of the plants to threaten. The study was carried out in three randomly selected districts in Northern Gombe State, Nigeria. Among all, $80 \%$ of the respondents are male among which $56 \%$ are 35 years and above. 43 plants were reported used as ethnoveterinary plants in the area (oral interview) among which only 28 were found to be present in the field (field assessment). Guiera senegalensis is the most abundant plant (7.85\%) followed by Piliostigma reticulatum $(7.23 \%)$, Combretum collinum and Detarium microcarpum (3.00\% both). Fabaceae is the most abundant family $(30.85 \%)$ of the identified plants followed by Combretaceae $(15.25 \%)$. Plant bark is the most common part used in curing and preventing animals from diseases which subject some of the plants (Burkia africana) to nearly endangered states. 28 plant samples were collected, identified, pressed, and laid in Botany Department Herbarium, Gombe State University, among these, 2 plant samples were not successfully identified. It is recommended that regulatory bodies should be empowered to check the uncontrolled deforestation occurring in the area
\end{abstract}

\section{INTRODUCTION}

Livestock production in Sub-Saharan African countries is severely constrained by the presence of a wide range of animal diseases and is believed to be growing at half the rate required to make significant in-roads in reducing poverty [1]. These diseases not only affect the production and productivity of livestock but also seriously hamper any meaningful livestock trade. Potentially fatal diseases in cattle include Foot-and-Mouth Disease (FMD) and Contagious Bovine Pleural Pneumonia (CBPP). For many years, these diseases have been causing serious problems in livestock production, especially among the poor rural farming communities. This problem is exacerbated by the farmers' lack of access to conventional livestock management skills and financial resources to afford vaccines and curative substances [2]. But there is potential for increasing production if disease control and management strategies are appropriately undertaken.
Ethnoveterinary practice is referred to as a method of healing livestock traditionally using various parts of different species of plants, especially the roots, stem, leaves, and grasses. The utilization of ethnoveterinary medicinal plants for the treatment of various diseases has been part of human traditions since ancient times and still increasing in many developed and developing countries [3]. Ethnoveterinary plant medications play a great contribution and are the most important sources of therapeutics for more than $90 \%$ of the livestock population [4].

Most livestock farmers in Nigeria are resource-poor [5]. It is, therefore, important that disease control strategies aimed at making it affordable and readily available to farmers. This cannot be achieved by adopting disease control strategies that are dependent on imported veterinary drugs but those based on cheaper, safer, and sustainable such as the use of locally and naturally derived drugs from plants. In recent years, there has 
been a remarkable rise in medicinal plants' use, probably due to their local abundance, cultural significance, and inexpensive procurement [6]. According to [7], the medicinal plants used for the control and management of diseases are cheaper, readily available, and can be used as a complement for the expensive synthetic drugs that are often in short supplies. The knowledge of medicinal plants and traditional beliefs of diseases management techniques used among the pastoral herders is said to have been developed gradually over a period of practical experience.

Millions of people around the world have an intimate relationship with their livestock. Animals provide them with food, cloth, labor, fertilizers, cash and act as a store of wealth and a medium of exchange. Animal health could be managed traditionally via Ethnoveterinary medicine (EVM) practices which are practices that involve a solid amalgamation of herbal knowledge and ancestral experiences [8]. The ethnoveterinary systems are ecosystem and ethnic-community specific and therefore, the characteristics, sophistication, and intensity of these systems differ greatly among individuals, societies, and regions.

However, they are facing the threat of rapid erosion because of rapid socio-economic, environmental, and technological changes. Even though indigenous knowledge systems are rapidly disappearing under the influence of Western culture, $80 \%$ of the world's population exclusively relies on traditional medicine. Especially in developing countries, traditional medicine has remained the main alternative treatment due to the shortage of pharmaceutical products and their unaffordable prices [9].

In Nigeria, as in many tropical countries of the world, many rural households have limited access to conventional veterinary drugs. This is due to poor access to urban areas to purchase these drugs and their generally high cost [10]. Thus, many people resort to the use of medicinal plants in the treatment of their animals [11]. Medicinal plant extracts and their constituents have proved to be biodegradable, have low mammalian toxicity, and have low induction of resistance [12]. Biodiversity has always been of utmost importance for the provision and discovery of medical substances [13].

Some of the common methods for administering ethnoveterinary medicines include drenching, nasal, and eye drop: This involves the oral and drops administration of medicine in liquid form [14]. Fumigation: The use of smoke or fumes to drive away or kill insects and other pests. Powdered material or dried leaves, dung, and bark are burnt in clay pots or on the open ground [15]. The documentations of traditional veterinary care used for the control and management of livestock diseases are the appropriate means of identifying potential sources of new drugs. Many traditionally plant base animal healing give rise to an increase in the potential modern drugs as they mostly retain the same constituents and uses.

Seventy-four percent of plant-derived compounds currently used in pharmaceuticals, retained similar use as used by traditional healers [16]. The knowledge of ethnoveterinary plants is on the verge of irreversible loss and decline. However, an alarming loss of biodiversity is occurring, particularly in mountain regions as they are disproportionally vulnerable to land-use change and climate change [17]. Drought and conflicting activities result in the migration of pastoralists many of whom acquire knowledge of treating and preventing their livestock from diseases traditionally using plants [18]. The population of these plants is currently dwindling due to overutilization, overexploitation, deforestation for fuelwood and farmland. Due to these problems, the dependence on modern veterinary medicine alone cannot solve most of the animal health problems. Therefore, there is a need for identification and documentation of the diseases, plants, and methods of control to avoid the extinction of this knowledge. The study aims to assess the ethnoveterinary plants and ethnoveterinary practices in Northern Gombe State, Nigeria and to identify the plants use in curing some of the animal diseases. In addition, other aims are to determine the plant part used in treating the diseases and to determine the diversity and abundance of the plants in the locality.

\section{MATERIALS AND METHOD}

\section{Study Area}

The study was carried out in Northern part of Gombe State, Nigeria. Gombe State is located in the Savannah belt of Northeastern Nigeria, the Northern part of Gombe State is between latitudes $10^{\circ} 49^{\prime} \mathrm{N}$ and $10^{\circ} 46^{\prime} \mathrm{E}$. It covers an area of 3815 square kilometers with a land area of 181,600 hectares. It has an estimated population of 207,658 as of March 2006, with $33 \%$ (68527) made of women of childbearing age (15-49years). The area is characterized by a mean annual rainfall range between $1200 \mathrm{~mm}-1500 \mathrm{~mm}$ and the temperature characteristics are typical of West African savanna climate [19].

\section{Type and source of data}

Both primary and secondary source of data was used in obtaining information and samples.

Primary sources are basically: Oral interview which was used in obtaining information about ethnoveterinary practices in the study area and Fieldworks carried out after the semi-structured interview which includes field assessment, plant sample collection, and pressing, and the determination of the occurrence, abundance, and diversity of the plants using appropriate ecological methods

Secondary sources are generally published journals, reviews, textbooks, Google Scholar e.t.c.

\section{Equipment and materials used in data collection}

Camera for clear photographs of the plants during data collection, GPS coordinate: for the determination of elevation of each collected plant sample, Datasheet, pencils and razor blade for labeling, pruning shear/scissors for cutting plant part, Newspaper and Plant press for pressing of collected plant samples.

\section{Research procedure/method}

Three districts were randomly selected in the Northern part of Gombe State. Information about ethnoveterinary plants and practices in each of the districts was obtained using oral interviews. A field assessment of the plants mentioned during the interview was conducted and data was recorded. The abundance and diversity of the plants were determined using appropriate ecological methods. Plants collected were pressed, identified, and laid in the Herbarium of the Department of Botany, Gombe State University.

\section{Data Analysis}

Data obtained were analyzed for Frequency, Abundance, Density, relative frequency, relative abundance, and Simpson diversity index using the following formulas;

Frequency $(\mathrm{F})=\times 100$

Relative frequency $(\mathrm{RF})=\times 100$

Density (d) =

Relative density $(\mathrm{RD})=\times 100$

Abundance $(\mathrm{A})=\times 100$ 
Relative abundance $(\mathrm{RA})=\times 100$

Important value index $=\mathrm{RF}+\mathrm{RD}+\mathrm{RA}$

Where $\mathrm{RF}=$ Relative frequency, $\mathrm{RD}=$ Relative density and $\mathrm{RA}=$

Relative abundance

Simpson Index (D) =

To get the actual value, Simpson index adopted 1-D

Whereby

$\mathrm{n}_{\mathrm{i}}=$ number of plants of each particular species

$\mathrm{N}=$ number of plants of all species. That is, Total number of all plants in each transect.

\section{RESULT}

A total number of 50 randomly selected respondents were interviewed, 44 males and 6 females. Majority of the respondents are males $(88.0 \%)$ with only a few females (Table 1). Among all, the older individuals (with 35 and above years) represent the highest respondents, and this may be attributed to their knowledge of the ethnoveterinary plants and practices, whereas the younger ones know the plants but do not specifically know their ethnoveterinary roles.

Table 1. The Number and frequency of respondents with gender and age.

\begin{tabular}{lllll}
\hline & $\begin{array}{l}\text { Number } \\
\text { respondents }\end{array}$ & of & $\begin{array}{l}\text { Frequency } \\
\text { respondents }\end{array}$ & of \\
\hline Age group & Male & Female & Male & Female \\
\hline $15-25$ & 6 & 0 & $12.00 \%$ & $0.00 \%$ \\
$25-35$ & 10 & 2 & $20.00 \%$ & $4.00 \%$ \\
Above 35 & 28 & 4 & $56.00 \%$ & $8.00 \%$ \\
Total & 44 & 6 & $88.00 \%$ & $12.00 \%$
\end{tabular}

A total number of 43 plants belonging to 15 families were used by the pastoralists as ethnoveterinary medicinal plants in curing 24 animal diseases in the study area (Table 2). Among all, 28 plants belonging to 15 families were found present in the field, the number of Occurrences, Frequency, Relative Frequency, Density, Relative Density, Abundance, Relative Abundance and Important Value Index in all the transects studied have been determined. The most abundant plants are Guiera senegalensis, Piliostagma reculatum and Combrettum collinum (Table 3 ).

The life form (habit) of each plant found in the field is shown in Table 4 below. The most abundant family among all the studied ethnoveterinary medicinal plants is Fabaceae followed by Combretaceae and the least abundant are Mimosaceae, Moraceae, and Sapotaceae (Table 5). It appears that most of the plants are trees with few annual undershrubs and shrubs.

The plant part used shows that bark is the highly used ethnoveterinary plant part followed by leaf (uncrushed) and leaf $\&$ bark. The low-used parts are seeds, bark \& root, and crushed seed (Table 6). The species diversity was determined using Simpson's diversity. It is known that Simpsons value/index close to 1 represents a high diversity and vice versa. Therefore, the ethnoveterinary plants are more diverse in the area as the value of the Simpson index is almost or nearly close to 1 (Table 7).

Table 2. The orally interviewed/assessed plant species, the plant part used, animal disease cured, animal cured, and the method of preparation of the ethnoveterinary medicine.

\begin{tabular}{|c|c|c|c|c|}
\hline $\begin{array}{l}\text { Plant } \\
\text { name }\end{array}$ & $\begin{array}{l}\text { Plant Part } \\
\text { used }\end{array}$ & Animal disease & $\begin{array}{l}\text { Animal } \\
\text { cured }\end{array}$ & $\begin{array}{l}\text { Method of } \\
\text { preparation }\end{array}$ \\
\hline$\overline{\text { Vitellaria paradoxa }}$ & Bark & Snake bite & Sheep \& ram & decoction \\
\hline Guiera senegalensis & Bark & $\begin{array}{l}\text { Snake bite } \\
\text { Placental } \\
\text { retention and }\end{array}$ & \multicolumn{2}{|c|}{ Cow, sheep \& ram decoction } \\
\hline Ceiba pentandra & Bark & fever & Cows & decoction \\
\hline $\begin{array}{l}\text { Dichrostachys cinerea } \\
\text { spp. africana } \\
\text { Commiphora africana }\end{array}$ & $\begin{array}{l}\text { Crushed } \\
\text { leaf }\end{array}$ & Diarrhea & \multicolumn{2}{|c|}{ Cow, sheep \& ram decoction } \\
\hline var. africana & Bark & Fever & All ruminants & decoction \\
\hline Sclerocarya birrea & Bark & $\begin{array}{l}\text { Appetizer } \\
\text { Breathing }\end{array}$ & \multicolumn{2}{|c|}{ Cow, sheep \& ram decoction } \\
\hline Borassus aethiopum & $\begin{array}{l}\text { Root } \\
\text { Seed }\end{array}$ & problem & Cows & decoction \\
\hline Acacia nilotica & crushed & diseases & \multicolumn{2}{|c|}{ Cow, sheep \& ram infusion } \\
\hline Anogeisus leiocarpa & Bark & $\begin{array}{l}\text { Stomachic worm } \\
\text { Placental }\end{array}$ & Sheep \& ram & infusion \\
\hline Tamarindus indica & Leaf & $\begin{array}{l}\text { retention } \\
\text { Placental }\end{array}$ & Cows & decoction \\
\hline Adansonia digitata & Leaf & retention & Sheep \& ram & $\begin{array}{l}\text { eat fresh } \\
\text { infusion in }\end{array}$ \\
\hline Balanites aegyptiaca & $\begin{array}{l}\text { Leaf } \\
\text { Crushed }\end{array}$ & Eye problem & \multicolumn{2}{|c|}{ Cow, sheep \& ram drop } \\
\hline $\begin{array}{l}\text { Crossopteryx febrifuga } \\
\text { Securidaca }\end{array}$ & Seed & Brucellosis & \multicolumn{2}{|c|}{ Cow, sheep \& ram Infusion } \\
\hline longepedunculata & Leaf \& bark & Stomachic worm & Sheep and ram & decoction \\
\hline Acacia Senegal & $\begin{array}{l}\text { Leaf \& bark } \\
\text { Crushed }\end{array}$ & Joint pain & Cows & $\begin{array}{l}\text { decoction } \\
\text { add powder }\end{array}$ \\
\hline Daniellia oliveri & bark & Milk ejection & New born & $\begin{array}{l}\text { to feed } \\
\text { decoction or }\end{array}$ \\
\hline Khaya senegalensis & Bark & Stomacl & Cow, sheep \& ram & infusion \\
\hline Azadirachta indica & Leaf & Fever & \multicolumn{2}{|c|}{$\begin{array}{l}\text { Cow, sheep \& ram decoction } \\
\text { Cow, sheep \& }\end{array}$} \\
\hline un-identified (baucihi) & Bark \& root & t No enough milk & ram & decoction \\
\hline Senna singueana & Flower & Helmintosis & Cows & decoction \\
\hline Steculia setigera & Flower & Blood stimulant & \multicolumn{2}{|c|}{ Cow, sheep \& ram decoction } \\
\hline Ficus platyphylla & Bark & Appetizer & Sheep \& ram & decoction \\
\hline Acacia albida & Leaf \& bark & Immunization & \multicolumn{2}{|c|}{ Cow, sheep \& ram decoction } \\
\hline Burkia africana & Bark & Blood stimulant & Cows & decoction \\
\hline Vitex simplicifolia & Bark & Mastitis & All ruminants & decoction \\
\hline $\begin{array}{l}\text { Combretum collinum } \\
\text { ssp. geitonophyllum }\end{array}$ & & & & \\
\hline ssp. geitonophyllum & Bark & Cancer & Cows & decoction \\
\hline Epiphyte of kapok & Leaf & Cancer & \multicolumn{2}{|c|}{ Cow, sheep \& ram decoction } \\
\hline Steculia setigera & Bark & Blood stimulant & All ruminants & $\begin{array}{l}\text { decoction } \\
\text { decoction }\end{array}$ \\
\hline $\begin{array}{l}\text { Bombax costatum } \\
\text { Euphorbia }\end{array}$ & Bark & $\begin{array}{l}\text { Eye problem } \\
\text { Breathing }\end{array}$ & All ruminants & drop \\
\hline convolvuloides & Leaf & problem & All ruminants & decoction \\
\hline Kalanchoa pinnata & Seed & $\begin{array}{l}\text { Poultry fever } \\
\text { Poultry }\end{array}$ & Chickens & Infusion \\
\hline Mangifera indica & Bark & immunization & All poultries & Infusion \\
\hline Prossopis africana & Bark & $\begin{array}{l}\text { Poultry diarrhea } \\
\text { Cancer and }\end{array}$ & Chickens & Infusion \\
\hline $\begin{array}{l}\text { Cassia arereh; } C . \\
\text { sieberana }\end{array}$ & Bark & $\begin{array}{l}\text { breathing } \\
\text { problem } \\
\text { Snake bite and }\end{array}$ & Cow & Decoction \\
\hline $\begin{array}{l}\text { Parkia biglobosa } \\
\text { Annona senegalensis \& }\end{array}$ & Bark & cancer & All ruminants & Decoction \\
\hline G. senegalensis & $\begin{array}{l}\text { Leaf } \\
\text { Crushed }\end{array}$ & $\begin{array}{l}\text { Stomach cancer } \\
\text { Stomach }\end{array}$ & All ruminants & Decoction \\
\hline Ficus platyphylla & $\begin{array}{l}\text { bark } \\
\text { Seed }+ \\
\text { potash }\end{array}$ & Cold and cough & Small ruminants & $\begin{array}{l}\text { Decoction } \\
\text { mix powder } \\
\text { with feed }\end{array}$ \\
\hline Piliostigma reticulatum & Root & Stomachic worm & New born & Infusion \\
\hline $\begin{array}{l}\text { Unidentified and Vitex } \\
\text { simplicifolia }\end{array}$ & Bark & $\begin{array}{l}\text { Stunted growth } \\
\text { Gastrointestinal }\end{array}$ & All ruminants & Decoction \\
\hline $\begin{array}{l}\text { Striga hermontheca } \\
\text { Aristolochia albida; }\end{array}$ & All parts & problem & All ruminants & Infusion \\
\hline A. bracteolata & All parts & Snake bite & All ruminants & Decoction \\
\hline Vitex doniana & Leaf & Stomachic worm & Cow, sheep \& ram & Decoction \\
\hline
\end{tabular}


Table 3. Important Value Index for each of the plant studied.

\begin{tabular}{|c|c|c|c|c|c|c|c|c|}
\hline Plant species & NI & $\mathrm{F}$ & RF & $\mathrm{D}$ & $\mathrm{RD}$ & $\mathrm{A}$ & RA & I.V.I \\
\hline Acacia seiberiana & 1 & 3.57 & 0.51 & 0.17 & 0.52 & 1 & 1.88 & 2.91 \\
\hline Adansonia digitata & 8 & 28.57 & 4.1 & 1.33 & 4.08 & 2.66 & 5.02 & 13.2 \\
\hline Anogeisus leiocarpus & 1 & 3.57 & 0.51 & 0.17 & 0.52 & 1 & 1.88 & 2.91 \\
\hline Balanite aegyptiaca & 6 & 21.42 & 3.07 & 1 & 3.07 & 2 & 3.77 & 9.91 \\
\hline Bombax costatum & 3 & 10.71 & 1.53 & 0.5 & 1.53 & 1.5 & 2.83 & $5.8 \mathrm{~S} 9$ \\
\hline Borassus aethiopum & 3 & 10.71 & 1.53 & 0.5 & 1.53 & 1.5 & 2.83 & 5.89 \\
\hline Burkia africana & 1 & 3.57 & 0.51 & 0.17 & 0.52 & 1 & 1.88 & 2.91 \\
\hline Ceiba pentandra & 1 & 3.57 & 0.51 & 0.17 & 0.52 & 1 & 1.88 & 2.91 \\
\hline Combrettum collinum & 15 & 53.57 & 7.69 & 2.5 & 7.68 & 3 & 5.66 & 21.04 \\
\hline Detarium & & & & & & & & \\
\hline $\begin{array}{l}\text { microcarpum } \\
\text { Dichrostachys }\end{array}$ & 12 & 42.85 & 6.15 & 2 & 6.14 & 3 & 5.66 & 18 \\
\hline $\begin{array}{l}\text { glomerata } \\
\text { Euphorbia }\end{array}$ & 1 & 3.57 & 0.51 & 0.17 & 0.52 & 1 & 1.88 & 2.91 \\
\hline convolvuloides & 4 & 14.28 & 2.05 & 0.67 & 2.05 & 1.33 & 2.51 & 6.61 \\
\hline Ficus sur & 1 & 3.57 & 0.51 & 0.17 & 0.52 & 1 & 1.88 & 2.91 \\
\hline Guiera senegalensis & 25 & 89.28 & 12.82 & 4.17 & 12.81 & 4.16 & 7.85 & 33.53 \\
\hline Khaya senegalensis & 1 & 3.57 & 0.51 & 0.17 & 0.52 & 1 & 1.88 & 2.91 \\
\hline Mangifera indica & 6 & 21.42 & 3.07 & 1 & 3.07 & 2 & 3.77 & 9.94 \\
\hline $\begin{array}{l}\text { Parkia biglobosa } \\
\text { Piliostigma }\end{array}$ & 18 & 64.28 & 9.23 & 3 & 9.22 & 3 & 5.66 & 24.11 \\
\hline reticulatum & 23 & 83.14 & 11.79 & 3.83 & 11.77 & 3.83 & 7.23 & 30.77 \\
\hline Prosofis africana & 10 & 35.71 & 5.12 & 1.67 & 5.13 & 2 & 3.77 & 14.05 \\
\hline Sclerocarya birrea & 9 & 32.14 & 4.61 & 1.5 & 4.61 & 3 & 5.66 & 14.88 \\
\hline Senna occidentalis & 1 & 3.57 & 0.51 & 0.17 & 0.52 & 1 & 1.88 & 2.91 \\
\hline Senna singueana & 11 & 39.28 & 5.64 & 1.83 & 5.62 & 2.75 & 5.19 & 16.45 \\
\hline Sterculia setigera & 4 & 14.28 & 2.05 & 0.67 & 2.05 & 1.33 & 2.51 & 6.61 \\
\hline Tamarindus indica & 10 & 35.71 & 5.12 & 1.67 & 5.13 & 2 & 3.77 & 14.05 \\
\hline Un-identified & 12 & 42.85 & 6.15 & 2 & 6.14 & 2.4 & 4.53 & 16.87 \\
\hline Vitellaria paradoxa & 3 & 10.71 & 1.53 & 0.5 & 1.53 & 1.5 & 2.83 & 5.89 \\
\hline Vitex doniana & 2 & 7.14 & 1.02 & 0.33 & 1.01 & 1 & 1.88 & 3.91 \\
\hline Vitex simplicifolia & \multirow{2}{*}{\multicolumn{2}{|c|}{195697.32}} & 1.53 & 0.5 & 1.53 & 1 & 1.88 & 4.94 \\
\hline $\begin{array}{l}\text { Grand Total } \\
\text { KEYS }\end{array}$ & & & 99.88 & 32.53 & 99.86 & 52.96 & 99.85 & 299.82 \\
\hline \multicolumn{9}{|c|}{$\begin{array}{l}\text { KEYS } \\
\text { NI: Number of individual plants }\end{array}$} \\
\hline \multicolumn{9}{|c|}{$\begin{array}{l}\text { F: Frequency } \\
\end{array}$} \\
\hline \multicolumn{9}{|l|}{ RF: Relative frequency } \\
\hline \multicolumn{9}{|l|}{ A: Abundance } \\
\hline \multicolumn{9}{|l|}{ RA: Relative Abundance } \\
\hline \multicolumn{9}{|l|}{ D: Density } \\
\hline & & & & & & & & \\
\hline
\end{tabular}

Table 4. The field determined ethnoveterinary plant species and their growth habits.

\begin{tabular}{ll}
\hline Plant species & Plant growth habit \\
\hline Acacia seiberiana & Tree \\
Adansonia digitata & Tree \\
Anogeisus leiocarpus & Tree \\
Balanite aegyptiaca & Tree \\
Bombax costatum & Tree \\
Borassus aethiopum & Tree \\
Burkia africana & Tree \\
Ceiba pentandra & Tree \\
Combrettum collinum & Tree \\
Detarium microcarpum & Tree \\
Dichrostachys glomerata & Tree \\
Euphorbia convolvuloides & Herbaceous \\
Ficus sur & Tree \\
Guiera senegalensis & Shrub \\
Khaya senegalensis & Tree \\
Mangifera indica & Tree \\
Pakia biglobosa & Tree \\
Piliostigma reticulatum & Tree \\
Prosofis africana & Tree \\
Sclerocarya birrea & Tree \\
Senna occidentalis & Annual undershrub \\
Senna singueana & Annual undershrub \\
Sterculia setigera & Tree \\
Tamarindus indica & Tree \\
Un-identified (Dogi) & Tree \\
Vitellaria paradoxa & Tree \\
Vitex doniana & Tree \\
Vitex simplicifolia & Tree \\
&
\end{tabular}

Table 5. The families of the studied ethnoveterinary plants.

\begin{tabular}{|c|c|c|c|}
\hline Family & $\begin{array}{l}\text { Number } \\
\text { occurence }\end{array}$ & f & $\begin{array}{l}\text { Relative } \\
\text { Abundance }\end{array}$ \\
\hline Anacadiaceae & 15 & 3 & 6.53 \\
\hline Arecaceae & 3 & 1.5 & 3.26 \\
\hline Combretaceae & 42 & 7 & 15.25 \\
\hline Euphorbiaceae & 4 & 1.33 & 2.89 \\
\hline Fabaceae & 85 & 14.16 & 30.85 \\
\hline Lamiaceae & 2 & 2 & 4.35 \\
\hline Malvaceae & 15 & 3 & 6.53 \\
\hline Meliaceae & 1 & 1 & 2.17 \\
\hline Mimosaceae & 1 & 1 & 2.17 \\
\hline Moraceae & 1 & 1 & 2.17 \\
\hline Sapotaceae & 3 & 1.5 & 3.26 \\
\hline Steculiaceae & 2 & 2 & 4.35 \\
\hline Verbenaceae & 3 & 3 & 6.53 \\
\hline Zygophyllaceae & 6 & 2 & 4.35 \\
\hline Unidentified & 12 & 2.4 & 5.22 \\
\hline Grand Total & 195 & 45.89 & 99.88 \\
\hline
\end{tabular}

Table 6. Plant part used, the number of occurrences used in curing animal diseases, and the relative frequency of each.

\begin{tabular}{|c|c|c|}
\hline Plant part & $\begin{array}{l}\begin{array}{l}\text { Number } \\
\text { occurrence }\end{array} \text { of } \\
\end{array}$ & $\begin{array}{l}\text { Relative } \\
\text { Frequency }\end{array}$ \\
\hline All parts & 2 & $4.65 \%$ \\
\hline Bark & 18 & $41.9 \%$ \\
\hline Bark and Root & 1 & $2.32 \%$ \\
\hline Crushed Bark & 2 & $4.65 \%$ \\
\hline Crushed Leaf & 1 & $2.32 \%$ \\
\hline Flower & 2 & $4.65 \%$ \\
\hline Leaf & 8 & $18.6 \%$ \\
\hline Leaf and Bark & 3 & $6.97 \%$ \\
\hline Root & 2 & $4.65 \%$ \\
\hline Seed & 1 & $2.32 \%$ \\
\hline Seed + potash & 1 & $2.32 \%$ \\
\hline Crushed Seed & 2 & $4.65 \%$ \\
\hline Total & 43 & $100 \%$ \\
\hline
\end{tabular}

Table 7. Simpson's diversity index of the ethnoveterinary plant species in each of the six (6) laid transects.

\begin{tabular}{lllll}
\hline Transect & $\mathrm{N}(\mathrm{N}-1)$ & & $1-\mathrm{D}$ & \\
\hline 1 & 92 & 1056 & 0.087 & 0.91 \\
2 & 54 & 992 & 0.054 & 0.94 \\
3 & 130 & 2550 & 0.051 & 0.95 \\
4 & 30 & 380 & 0.079 & 0.92 \\
5 & 35 & 552 & 0.063 & 0.94 \\
6 & 66 & 1190 & 0.055 & 0.95 \\
Average & 67.83 & 1120.00 & 0.06 & 0.94
\end{tabular}

\section{DISCUSSION}

A total number of 50 respondents all of which are Fulani were interviewed among which 46 are males with only 4 females. About 28 of the respondents fall within the range of 35 . This result is in agreement with [20] and [21] who reported the age range of 21-50 being the major herdsmen in their study. Among all, only the older peoples ( 35 and above) with few below 35 years were found to be self-practitioners. The frequency and relative frequency, density and abundant of the plants shows that Gueira senegalensis is the most frequent, dense and abundant ethnoveterinary plant species in the study area followed by Pilliostigma reticulatum, Parkia biglobossa and Acacia seiberiana, Balanite aegyptiaca, Burki africana, Ceiba pentandra, Euphobia convolvuloides e.t.c are the less frequent, dense and abundant plants. Also, Family Fabaceae represent the largest family with abundant plants species followed by Combretaceae and Moraceae, Mimosaceae, and Sapotaceae. This is in agreement with [22] who report Fabaceae as the most abundant ethnoveterinary plant family. 
The percentage of plant parts used in curing animal diseases shows that; plant bark represents the highest percentage followed by leaf. This is not in agreement with [23] who reported root and leaf as the most plant part used with the root being the most frequent. Based on this, most of the bark overused plants were threatened (Burkia africana) with others endangered (Crossopteryx febrifuga), others are in a state of danger due to deforestation and overexploitation activities for farmland (Combrettum collinum, Piliostigma reticulatum) and timber by industries (Parkia biglobosa). This is in agreement with [24] who reported that there is an increasing threat to wild plant resources and their habitats because of overexploitation.

\section{CONCLUSION}

In conclusion, 43 plant species belonging to 15 families were used as ethnoveterinary plants in the study area for curing 24 animal diseases. The frequency of plant parts used as ethnoveterinary shows that bark is the highly used plant part followed by leaves in the study area. The most abundant plants are Gueira senegalensis, Pilliostigma reticulatum, Parkia biglobossa, Combrettum collinum e.t.c. The ethnoveterinary plants are more diverse (0.94) as calculated using Simpson's diversity index). It is recommended that regulatory bodies shall be empowered to check the uncontrolled deforestation occurring in the area. It is also recommended that the conservational status of these plants should be frequently observed to avoid the extinction of the plants in the areas.

\section{REFERENCES}

1. Ahemen T, Zahraddeen D. Species contribution as a source of meat and their foetal wastage in Taraba State, Nigeria. Archives of Appl Sci Research. 2010;2(5):85-91.

2. Gabalebatse M, Ngwenya BN, Teketay D, Kolawole OD. Ethnoveterinary practices amongst livestock farmers in Ngamiland District, Botswana. Afr J Traditional, Complementary and Alternative Med. 2013 May 1;10(3):490-502

3. Yadav SS, Bhukal RK, Bhandoria MS, Ganie SA, Gulia SK, Raghav TB. Ethnoveterinary medicinal plants of Tosham block of district Bhiwani (Haryana) India. J Appl Pharmaceutical Sci. 2014 Jun 1;4(6):40.

4. Teklay A, Abera B, Giday M. An ethnobotanical study of medicinal plants used in Kilte Awulaelo District, Tigray Region of Ethiopia. J ethnobiology and Ethnomed. 2013 Dec;9(1):1-23.

5. Usman IS. Ethno-veterinary care amongst the nomadic Fulani herdsmen in the southern zone of Adamawa State, Nigeria. J Anim Sci Vet Med. 2016 Dec;1:108-17.

6. Thomford NE, Dzobo K, Chopera D, Wonkam A, Skelton M, Blackhurst D, Chirikure S, Dandara C. Pharmacogenomics implications of using herbal medicinal plants on African populations in health transition. Pharmaceuticals. 2015 Sep;8(3):637-63

7. Mathias E. Ethno-veterinary development: Integrating local knowledge with modern Sci. In13th DIO Symposium "Ethnoveterinary medicine", organized by the Foundation for Veterinary Medicine in Developing Cooperation (DIO), The Huge, The Netherlands, 13th December 2001.

8. Mesfin F, Demissew S, Teklehaymanot T. An ethnobotanical study of medicinal plants in Wonago Woreda, SNNPR, Ethiopia. J Ethnobiol Ethnomed. 2009 Dec;5(1):1-

9. Bekele D, Asfaw Z, Petros B, Tekie H. Ethnobotanical study of plants used for protection against insect bite and for the treatment of livestock health problems in rural areas of Akaki District, Eastern Shewa, Ethiopia. Topclass J Herb Med. 2012;1(2):12-24.

10. Saganuwan AS, Gulumbe ML. Evaluation of in-vitro antimicrobial activities and phytochemical constituents of Cassia occidentalis. Anim Res Int. 2006;3(3):566-9.

11. Bahmani M, Eftekhari Z. An ethnoveterinary study of medicinal plants in treatment of diseases and syndromes of herd dog in southern regions of Ilam province, Iran. Compar Clin Pathol, 2013;22(3):403-407.

12. Adebajo AC, Famuyiwa FG, John JD, Idem ES, Adeoye AO Activities of some Nigerian medicinal plants against Aedes aegypti. Chinese Med, 2012;3(3):151-156.

13. Neergheen-Bhujun V, Awan AT, Baran Y, Bunnefeld N, Chan K, Dela Cruz TE, Egamberdieva D, Elsässer S, Johnson MV, Komai S, Konevega AL. Biodiversity, drug discovery, and the future of global health: Introducing the biodiversity to biomedicine consortium, a call to action. J Glob Health. 2017 Dec;7(2).

14. Chowbey PK, Khullar R, Sharma A, Soni V, Baijal M, Garg N, Najma K. Laparoscopic management of infected mesh after laparoscopic inguinal hernia repair. Surgical laparoscopy, endoscopy \& percutaneous techniques. 2015 Apr 1;25(2):125-8.

15. Balakrishnan V, Robinson JP, Kasamy AM, Ravindran KC. Ethnoveterinary studies among farmers in Dindigul district Tamil Nadu, India. Global J Pharmacol. 2009;3(1):15-23.

16. Moonga $\mathrm{E}$, Chitambo $\mathrm{H}$. The role of indigenous knowledge and biodiversity in livestock disease management under climate change. In2nd International Conference: Climate, Sustainability and Development in Semi-arid Regions August 2010 (pp. 16-20).

17. Butchart SH, Walpole M, Collen B, Van Strien A, Scharlemann JP, Almond RE, Baillie JE, Bomhard B, Brown C, Bruno J, Carpenter KE. Global biodiversity: indicators of recent declines. Science, 2010;328(5982):1164-1168.

18. Sarasan V, Kite GC, Sileshi GW, Stevenson PC. The application of Phytochemistry and in vitro tools to the sustainable utilization of medicinal and pesticidal plants for income generation and poverty alleviation. Plant Cell Report, 2011;30:1163-72.

19. Baba MH, Saidu H, Faruk UU, Alhassan A. Limnological Studies of Gombe Abba River, Dukku Local Government Area of Gombe State, Nigeria. Int J Res Rev, 2020:7(7):455-471.

20. Faleyimu OI, Ijeomah HM, Oso AO. Medicinal utilization of roots of forest plants in Lere Local Government Area of Kaduna State, Nigeria. J Agric Soc Res, 2011;11(2):51-66.

21. Faleyimu O, Akinyemi O. Herbal approaches to the problem of erectile dysfunction in Kaduna State, Nigeria. Egypt J Biol. 2010;12:103-7.

22. Abrha HK, Gerima YG, Gebreegziabher ST. Indigenous Knowledge of Local Communities in Utilization of Ethnoveterinary Medicinal Plants and Their Conservation Status in Dess'a Priority Forest, Northeastern Escarpment of Ethiopia. Researchsquare.https://www.researchsquare.com/article/rs88909/latest. DOI: 10.21203/rs.3.rs-88909/v1. Accessed $9^{\text {th }}$ Dec 2021.

23. Ayehu M, Debebe D. Ethnoveterinary medicine knowledge and practices in and around Gondar, Ethiopia. Int J Pharm Pharm Sci, 2018:3(1):39-68.

24. Usman IS, Mani AU, Mohammed ID. Indigenous Foot and Mouth Disease Control Methods among Nomadic Cattle Fulanis in Adamawa State, Nigeria. Alex J Vet Sci. 2015 Apr 1;45. 